\title{
Using Social Media as a Managerial Platform for an Educational Development Project: Cofimvaba
}

\author{
Abraham Gert van der Vyver, B. Williams, and M. A. Marais
}

\begin{abstract}
This paper contains a qualitative analysis of selected excerpts from the managerial communication records of the Cofimvaba e-textbook project. This project is conducted in the Eastern Cape, a province of South Africa. The component managers of the project use Whatsapp, a popular social media platform to engage in managerial communication. The researchers found that this unconventional platform proved to be an excellent anchor for managerial communication on the project.
\end{abstract}

Index Terms-Managerial communication, social media, e-textbook, content analysis, group behavior.

\section{INTRODUCTION}

The commercialization of the Internet in 1995 and the subsequent development of a wave of new technologies created huge expectancies of job creation and the empowerment of the poor. New project initiatives, all rich with promise, were continuously announced. This was then followed in quite rapid and relatively well-publicised succession by reports of little-used or abandoned ICT projects, and by overall analyses that something like one-third of such projects were total failures, something like half were partial failures, and only a small minority succeeded [1]. This pattern is also detected in South Africa where the history of ICT4D in South Africa is also earmarked by spectacular and expensive failures. Attwood and Braathen reported that only $29 \%$ of the listed telecentres that they contacted were operational [2]. "While being absent from almost all official reports, the bureaucratic and administrative mechanisms behind the scenes of development projects heavily condition and constrain the possibilities for an effective introduction of technology in the school ecosystem [3]. In a comprehensive study on telecentres in Africa, Etta and Parvyn-Wamahiu found that "most of the telecentres experienced some management problems, ranging from poor attitudes, to weak management, technical and even social skills" [4]. Parkinson identified internal management and leadership as a key factor for sustainability of a development project and lists the following variables: vision/champion, capacity, cohesion versus complexity in decision making, level of internal conflict, ability to partner, network, technical know-how, marketing skills, flexibility and quick response"

Manuscript received March 31, 2014; revised August 12, 2014.

Abraham Gert van der Vyver is with School of IT, Monash SA, Ruimsig, South Africa (e-mail: Braam.vandervyver@monash.edu).

B. Williams is with Feedback Research and Analytics, Pretoria, South Africa (e-mail: bwilliams@feedback.co.za).

M. A. Marais is with the Meraka Institute, CSIR, Pretoria, South Africa (e-mail: MMarais@CSIR.co.za).
[5]. The addressing of a number of these variables by way of the innovative use of a social media platform forms the topic of this paper.

\section{LITERATURE REVIEW}

\section{A. Technology in Education}

A prominent eLearning project in Jamaica stated that "( $(\mathrm{t})$ he primary goal of the e-Learning project is to utilize Information and Communication Technologies (ICTs) to contribute to an improvement in the quality of education in the high schools, to enhance the learning experience and to improve the level of passes" [6]. This project is just one example of a myriad of initiatives that are aimed at the infusion and integration of technology in education. Unfortunately, not all projects end in glory. Wopereis, Kirschner, Paas, Stoyanov and Hendriks report on projects funded by stakeholders in the Netherlands. They reached the following conclusion: "Unfortunately, these highly funded initiatives often result in short-lived or local successes or outright failures [7]. They ascribe this trend to poor institutional, project, and process management. Another author cites 18 reasons why eLearning projects fail. Most of the reasons relate to poor managerial practices [3]. The e-Learning Jamaica project is anchored by a solid managerial backbone. The fact that 166 public high schools, 11500 teachers and 260000 students are involved poses numerous managerial challenges. The e-Learning Jamaica Project comprises of five components. These are: [6]

Component 1- Instructional Materials

Component 2 -Technology Infrastructure for Storage / Dissemination/ Access

Component 3 - Teacher Training

Component 4 - Remedial Support

Component 5 - Continuous Assessment

Despite this solid planning framework, the case study makes no mention of a managerial platform. With numerous sponsors and other stakeholders to strengthen the government's hand, the lack of solid management structures will almost certainly impact negatively on the progress of the project. Clashing interests will result in loss of trust and in-fighting which can be detrimental to any new initiative. The Cofimvaba project that features in this paper illustrates the presence of a solid platform for managerial communication.

\section{B. Using a Social Media Application for a Management Platform}

The social media in all its forms seem to be heading all the research agendas that may apply to it. This also goes for the 
domains of business and education. One management guru stated that "through the enabling powers of social tools we are facing the most profound change to the ways in which business is done since we built the pyramids" [8]. He also pointed out that "strategic agility requires feedback from the edges at which change is being experienced fastest" [8]. Gurstein [9] feels that "(t)he major failures in the use of ICTs for development have not been failures in technology, nor in software nor even in funding; rather the failures have been in the implementations."

This is where the social media comes in. Social media platforms like Facebook and Twitter makes it possible to generate a running commentary of feedback which can be used to effect managerial adjustments if and when needed. White evaluated the Jamaican project that was discussed in the previous section and recommended "using a technology management lens influenced by educational technologies, the digital divide, and the diffusion of innovation" to review educational development project [10]. Such a lens has been embedded in the Cofimvaba project that serves as a focus point of this paper.

\section{Behavior of Group/Team}

In 1965 Bruce Tuckman developed a 4-stage model of group development. He labelled the stages, Dr Suess-style. He made provision for the following stages:

1) Forming: The group comes together and gets to initially know one other and form as a group. This stage is earmarked by its directive nature and the autonomous behavior of group members. "Individual behavior is driven by a desire to be accepted by others, and avoid controversy or conflict. Serious issues and feelings are avoided" [11].

2) Storming: This is the stage where members are required to leave their comfort zones. Some members may vie for leadership positions. It is the right time for trialing of group processes. "The conflict will be more or less surpressed but it will be there, under the surface" [11].

3) Norming: Eventually agreement is reached on how the group operates. By now the rules of engagement have been established and there is certainty about their tasks and objectives.

4) Performing: The group practices its craft and becomes effective in meeting its objectives. Some members may dominate the group while others may engage in social loafing.

Tuckman added a 5 th stage 12 years later:

5) Adjourning: The process of "unforming" the group, that is, letting go of the group structure and moving on. This stage is about task completion, disengagement and closure [12], [13].

\section{The Cofimvaba Project}

Cofimvaba is a small town in the deep rural area of the Eastern Cape Province in South Africa. The name is also said to be derived from cofa, 'press', mvaba, 'milk-bag' (of goatskin) done to break lumps of sour milk [14].

TABLE I: A FRAMEWORK FOR MONITORING AND EVALUATION OF DEVELOPMENTAL PROJECTS [15]

\begin{tabular}{|c|c|c|}
\hline Key M\&E Actions & Component & Evaluation Questions \\
\hline \multirow{3}{*}{ Model Development } & $\begin{array}{c}\text { Documentation of theory of action and theory of } \\
\text { change }\end{array}$ & $\begin{array}{l}\text { What is the initial design and significant } \\
\text { modifications made to each of the } 12 \text { components } \\
\text { required to address in e-textbook rollout? }\end{array}$ \\
\hline & Design choice review & $\begin{array}{l}\text { Programme focus: } \\
\begin{array}{l}\text { What were the significant design choices for each } \\
\text { of the componentsModel focus: }\end{array}\end{array}$ \\
\hline & Cost Study & $\begin{array}{c}\text { Programme focus: } \\
\text { What was the total cost of implementing the } \\
\text { different designs of the programme? } \\
\text { Model focus: } \\
\text { What would the total cost be to implement such a } \\
\text { programme on district wide level? }\end{array}$ \\
\hline $\begin{array}{l}\text { Monitoring } \\
\text { \& Learning }\end{array}$ & Implementation monitoring & $\begin{array}{l}\text { Programme focus: } \\
\text { Was the programme components, and programme } \\
\text { overall, feasible to implement? } \\
\text { Model focus: } \\
\text { What have we learnt about the implementation of } \\
\text { this programme that should be transferred to } \\
\text { others? } \\
\text { Which factors support, inhibit or prevent } \\
\text { implementation? }\end{array}$ \\
\hline Evaluation \& Learning & $\begin{array}{c}\text { Results Review: } \\
\text { Reaction and learning at teacher, learner, } \\
\text { district level }\end{array}$ & $\begin{array}{l}\text { Programme focus: } \\
\text { Did the programme deliver the anticipated } \\
\text { educational outcomes } \\
\text { What were the unanticipated results? } \\
\text { Model focus: } \\
\text { What have we learnt about the results of this } \\
\text { programme that should be transferred to others? } \\
\text { Which factors support, inhibit or prevent the } \\
\text { realisation of outcomes? }\end{array}$ \\
\hline
\end{tabular}

"The Cofimvaba e-textbook pilot is a project funded by the Department of Science and Technology and Department of Rural Development and Land Reform in partnership with the Department of Basic Education and Eastern Cape 
Department of Education It is implemented by the CSIR Meraka Institute and aims to test tablets and other ICT technologies in 26 rural schools in the Nciba circuit in the Eastern Cape" [15].With four major government-related stakeholders involved i.e. two national departments, one provincial department and one government agency, it is clear that co-ordination and communication at managerial as well as grass roots level will be of paramount importance. Twelve component managers are responsible for the implementation of the project. They assist with the design as well as the collection of the evaluation information since they are all potential users of this information [15].

Since these component managers are responsible for the hands-on management of the project in the region, the empirical investigations are designed to analyse their communication. They used a popular social platform, Whatsapp, to deal with managerial communication. "The Whatsapp app is a SMS style program running on most smart phones and can be used to set up groups and allows members of the group to chat [16]. This decision raised a few eyebrows Not only has Whatsapp made its name as a platform for casual and platonic communication but it could only be used by owners of Smartphones. The question immediately arose whether all the component managers own and/or enjoy access to a Smartphone. If not, a managerial digital divide was on the cards. This issue immediately found its way onto the research agenda for the project.

Another aspect that features prominently on the research agenda is evaluation design. This type of design is driven by the aims and objectives of the project. Williams, Marais and Rampa declare that "the project aims to improve the teaching and learning environment, and intends to contribute towards improved learner results and the development of 21 st century skills among teachers and learners [15]. They added that "developmental Evaluation is considered to be appropriate for the e-Textbook Initiatives' purposes to learn and improve and its implementation requires constant monitoring and evaluation conducted and being fed back into the work of the e-Textbook Initiative" [15]. The learned authors proposed the following framework (see Table I) for the monitoring and evaluation of the project:

\section{Methodology}

From this framework, it is clear that the project is of a multi-dimensional nature. Since the focus of this part of the study was managerial communication, the researchers opted for an interpretive approach by analyzing the narratives that took place between the component managers. The discussions were recorded on the Whatsapp social platform. The study can thus by classified as a single case study. The first researcher started by conducting content analysis on a purposively-selected record of discussions that took place in a very early stage of the project. New participants who just joined the discussions were still being introduced. The researcher implemented a grounded theory approach by starting without a preconceived framework or typology. As he made progress with the analysis, a typology of managerial actions were established.

The second researcher then did content analysis on a purposively-selected set of discussions that took place once the forming stage of the team had been completed. Although one or two forming issues remained on the agenda, the majority of the discussions were now directed at operational issues.

\section{FINDINGS}

From the narrative analysis the researcher detected a managerial environment that is rich with relevant managerial activities. The analysis is divided into two sections i.e. afist in which group formation is addressed and a second in which the shift to operational issues is addressed.

\section{A. Getting Started}

The participants were out to establish a sound managerial backbone for the implementation of the project. The following typology of managerial activities were put together from one of the earliest conversations of the component managers:

- Agenda-setting: determining the main discussion field

- Co-ordinating: Co-ordinating participation

- Directional: Directing participants to an electronic and or physical venue

- Motivational: motivating individual or group to participate in one or more activities.

- Personal: Personal comment

- Arrangement: an arrangement between individuals (not pertaining to the whole group)

- Explanatory: Explaining an arrangement or previous comment

- Technological: giving technogical instructions and/or an explanation

- Managerial: planning, staffing, organizing, leading, controlling

- Confirming: Confirming an arrangement/comment

- Informational: providing general information

- Humorous: Work related/non-work related

- Declarative: declaring an intention/fact - "can't attend"

- Request: posing a request

- Expressive: expressing gratitude and/or other emotion

- Closing: ending the conversation

- Announcement: announcing a new initiative

- Reservation: Expressing a reservation/doubt "still one teacher though"

- Inquiry: General or detailed

\section{B. Getting Operational}

Once the team formation had been completed, a shift of emphasis towards operational issues were detected. The following additions to the typology was made:

- Problem solving: problems of individual team members

- Resource management :one teacher disappeared with a tablet

- Team requirements: Members not owning tablets

- Usage: Members not knowing how to use the tablets

- Platform policy: personal vs formal communication

\section{Establishing Progress}

Although the project is still in a very early stage, it is clear that the team development process has already completed 
Tuckman's forming stage. Minor conflict indicates that the storming stage has kicked in while the operational activities indicate that the norming stage has also been initiated.

To the untrained eye they text looks to contain low level managerial discussions however a more in-depth analysis uncovers a managerial environment that is rich in content and direction. The use of a highly unconventional social platform to host the discussions adds novelty to the findings.

\section{CONCLUSIONS}

The paper makes a sound theoretical contribution by illustrating the importance of constructive managerial communication in a development project. In the research domain the contribution lies in the use of content analysis on data generated form a social informatics platform and on the practical front, the use of Whatsapp as a managerial platform offers an unconventional as well as a novel approach.

\section{REFERENCES}

[1] R. Heeks, "Do information and communication technologies (ICTs contribute to development," J. Int. Devl., vol. 22, pp. 625-640, 2010

[2] H. Attwood and E. Braathen, "Telecentres an dpoor communities in South Africa: What have we learnt?" presented at the Chronic Poverty Research Centre Conference, 8-10 September 2010, Manchester, UK.

[3] Anon. 18 Reasons e-Learning Projects Fail. [Online]. Available: http://www.projectmanagingelearning.com/eighteen_reasons.html

[4] F. B. Etta and S. Parvyn-Wamahiu, "Information and communication technologies for development Africa," The Experience with Community Telecentres, Ottowa: International Development Research Centre, vol. 2, 2003.

[5] S. Parkinson, "Telecentres, access and development," Experience and Lessons from Uganda and South Africa, Kampala: ITDG, 2005.

[6] Ifip, "E-Learning Jamaica," presented at $12^{\text {th }}$ International Conference on Social Implications of Computers in Developing Countries, May 19-22, 2013, Jamaica.

[7] I. G. J. H. Wopereis, P. A. Kirschner, F. Paas, S. Stoyanov, and M. Hendriks, "Failure and success factors in educational ICT projects: a group concept mapping approach," Britsih Journal of Educational Technology, vol. 36, no. 4, 2005, pp. 681-684, Blackwell.

[8] G. Lauren, "Management: Social media's next big lesson organisational learning for superior strategy," Keeping Good Companies, vol. 64, no. 3, Apr. 2012, pp. 181-184.

[9] M. Gurstein, "The major failures in the use of ICTs for development have not been failures in technology, nor in software nor even in funding; rather the failures have been in the implementations," The Journal of Community Informatics, vol. 2, no. 2, 2006.

[10] K. A. White, "Lead, follow or get left behind: a grounded theory, qualitative study of e-learning Jamaica," presented at $12^{\text {th }}$ International Conference on Social Implications of Computers in Developing Countries, May 19-22, 2013, Jamaica.

[11] Chimaera Consulting. (November 27, 2013). Famous models. Stages of Group Development. [Online]. Available: http://www.chimaeraconsulting.com/tuckman.htm

[12] J. Neill. (November 26, 2013). What are the stages of group development? [Online]. Available: http://www.wilderdom.com/group/StagesGroupDevelopment.html

[13] Boundless. Stages of team development. [Online]. Available: http://www.boundless.com/management [cited 26 November 2013].

[14] Dictionary of Southern African place names, Pretoria: HRSC.

[15] B. Williams, M. Marais, and M. Rampa, "Evaluation design of the Cofimvaba e-textbook initiative."

[16] Chartered Management Institute. (November 27, 2013). Whatsapp use. [Online]. Available: http://www.managers.org.uk/practical-support/management-communit y/ask-the-expert/whatsapp-app-use

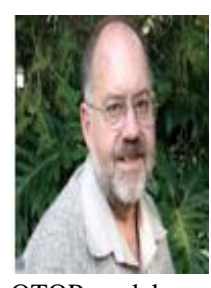

OTOP model.

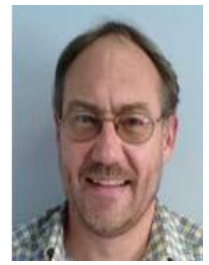

Mario Marais does his research in the technology, implementation, monitoring and evaluation research group of the Meraka Institute of the CSIR. His research areas include social capital in ICT for development, systems thinking in evaluation, and the integration of monitoring and evaluation into ICT4D project flow. He loves facilitation and problem structuring via soft operations research techniques. Currently his evaluation work includes an eTextbook project in rural schools, the use of iPads in schools and ICT-hubs for service delivery to rural communities. His recent work includes managing the M\&E of the Digital Doorway initiative, assessment of a horizon scanning project and business modelling for a project that provides Internet connectivity to schools and communities using wireless mesh technology. He held his masters degree in physical chemistry and theology, and is busy with a $\mathrm{PhD}$ in informatics.

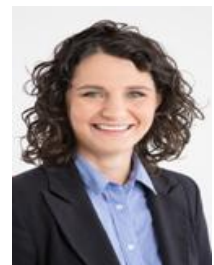

M. A. Marais is an evaluation consultant and the owner of Benita Williams Evaluation Consultants, a South African evaluation consultancy. Ms. Williams is responsible for the design, implementation and management of monitoring and evaluation projects. Recently she is focuses on the evaluation of education support initiatives, particularly initiatives employing ICTs for education and development. Ms Williams has academic training in the field of research psychology (University of Pretoria) and served as board member for the South African Monitoring and Evaluation Association (SAMEA) and the African Evaluation Association (AfrEA). 